\title{
The effects of oil pollution on populations of marine and coastal birds
}

\author{
FRIEDRICH GOETHE \\ Institut für Vogelforschung "Vogelwarte Helgoland“, Wilhelmshaven
}

KURZFASSUNG: Die Wirkungen der Ölverschmutzung auf Populationen von Meeres- und Küstenvögeln. Mit zunehmender Olverschmutzung des Meeres als Folge wachsenden OOltransportes mit Schiffen wuchsen die Gefahren für Vögel des marinen Pelagials und noch mehr des Litorals. Die durch die Verschmutzung mit Ol fast durchweg moribund gewordenen und unter verschiedenen Symptomen eingegangenen Vögel umfassen in Nord- und Ostsee über 20 Arten und können bei einer einzigen Katastrophe über 500000 Individuen ausmachen. Da nicht selten ganze Populationen von See- und Wasservogelarten außerhalb von Brutraum und Brutzeit auf relativ kleinem Raum zusammenkommen, besteht die Gefahr einer hochgradigen Dezimierung oder gar Bestandsauslöschung.

\section{INTRODUCTION}

Marine and coastal birds have often been neglected as important members of oceanic and coastal communities by marine biologists. Nevertheless, they play an important role in the economy of the sea, and, in particular, in regard to marine oil pollution.

Marine oil pollution and its detrimental effects on marine and coastal bird species have increased ever since the first oceangoing ship began to use oil as a fuel source. Oil pollution of the sea has been particularly aggravated by the recent increase in the fleet of oil tankers. In 1965, the world tonnage of oil tankers amounted to approximately 50 million BRT with a transport capacity of about one million tons of oil. Though we may refrain from discussing technological details, we should remember that at first the bile water, enriched with oil residues, later the residues from the tanks themselves, has been pumped overboard during the cleansing procedures. In addition, accidents involving big tankers have recently caused catastrophies and aroused world-wide concern. The thin iridescent surface oil film causes less damage to marine and coastal birds than the brownish coloured heavy oil drifting often in mile long bands or "lakes" on the water surface. Whether seabirds purposely frequent such "lakes" regarding them mistakingly as tang fields has not yet been proved. The relative calm water surface caused by the oil may also play a role in attracting birds. 


\section{DETRIMENTAL EFFECTS OF OIL}

The detrimental, usually lethal, effects of crude oil are complex. Upon contact with oil the feathers of breast, vent, and flanks of the bird become smeared with oil, resulting in the removal of air from between the small feathering. This, in turn, causes the loss of the thermo-isolating effect of the feather-enclosed air. Worse yet, even a bird lightly smeared with oil tends to preen itself continuously, thereby damaging the "mechanical lock" within its feathering. The protection against loss of body heat and water is being lost; the birds are unable to become airborne (for static reasons and as a result of their preening, soiling their wings as well in this process). Heat loss and heavily disturbed thermoregulation result in blood congestion, serious supercooling, and cessation of food absorption, leading to gradual fatigue, speeded up through the strenuous cleansing efforts.

In addition, crude oil has a caustic and inflaming effect on the epidermis and even more so on the digestive tract of the bird. In particular, examination of polluted Guillemots (Uria aalge) revealed oil residues in throat, stomach, and intestines, the latter usually being inflamed.

The detrimental effect of oil upon the birds' food ought to be considered as well. This problem will, however, be examined extensively by marine and fishery biologists during this international symposium.

\section{EXAMPLES OF DAMAGES TO BIRDS}

Prior to mentioning results of oil pollution studies by ornithologists, a few examples of oil pollution in the Baltic Sea and the Atlantic will be given.

\section{Baltic Sea}

Aside from many pollutions in the area of the island Fehmarn and at the Swedish coast in the fifties, a serious catastrophe occured in the Hohwacht Bay resulting from the release of about 500 tons of oil residues from an unknown ship in January, 1953. At least 10,000 dying and dead birds, chiefly Eiders (Somateria mollissima), Red-breasted Mergansers (Mergus serrator), Long-tailed Ducks (Clangula byemalis), Common and Velvet Scoters (Melanitta nigra and fusca), Black-throated Divers (Gavia arctica), Red-throated Divers (Gavia stellata), and Great-crested Grebes (Podiceps cristatus) drifted on to the beaches (Ecke 1957, Kunlemann 1953).

\section{North Sea}

The catastrophe of the Danish tanker "Gerd Maersk" stranded on the Scharhörn ridge in the outer Elbe river in the night from 16 th to 17 th of January, 1955, resulted in the release, for salvaging purposes, of 8,000 tons of crude oil into the sea. The 
expansion of the sea area polluted by this oil has been reported by the "Deutsches Hydrographisches Institut". At least 500,000 perished sea and water birds, belonging to 19 different species (with Common Scoters, Melanitta nigra, again ranging in the first place), were estimated by test counts.

\section{Atlantic}

While the collision of the Norwegian tanker "Anne Mildred Brøvig" with a British ship 40 sea miles west of Helgoland on February 10th, 1966, through successful salvage of the affected tanker portion under favorable weather conditions, did not lead to a catastrophe, the Liberian tanker "Torrey Canyon", 61,300 BRT, stranded and broke apart on the Seven Stone Rocks between the Scilly Islands and Cornwall on March 18th, 1967. Its total cargo of 117,000 tons of crude oil was lost to the sea. The results of this catastrophe on sea birds are not yet known as to their final details. The preliminary report by the president of the "International Council of Bird Preservation" (June, 1967) shows that this disaster led to the worst oil pollution of all times. Within 2 days 30,000 tons of oil gushed into the sea and a few days later 100 miles of Cornwall coast were totally polluted. In the ensuing weeks, more and more oil escaped from the wrecked tanker forming vast oil "lakes" on the sea surface. The event was considered a national catastrophe by the British government causing newspaper headlines in all the world. The large "lakes" of oil drifted into the Channel reaching the coast of Brittany on the 10th of April. A few days later, immense losses of birds on the "Seven Islands", a famous bird reserve, were recorded. Colonel Milon, President-Adjoint of the "Ligue Française pour la Protection des Oiseaux", in a first estimate announced that 4,400 Puffins (Fratercula arctica) perished and that on the island of Rouzic the population of Puffins was reduced from 5,000 to 600 , Razorbills (Alca torda) from 800 individuals to about 100, and Guillemots (Uria aalge) from 500 to 100 . Dying Gannets (Sula bassana), only slightly oiled, were found every day and in the centre of the colony about $10 \%$ of the breeding birds showed traces of oil, this number rising later to $20 \%$. It was further announced that the effects on the Cornish colonies were more difficult to estimate and that surveys are being made. At least 25,000 oiled and perished birds, mostly Guillemots and Razorbills, were estimated in the British South-West, but final numbers cannot be given before the actual census is concluded (last information by "The Nature Conservancy"). "The disaster could not have happened at a worse time, for both the English and the French colonies, as the birds were returning inshore to nest and migration was in full swing" (Central Secretariat 1967). The above examples may suffice. There were bad pollutions also in the Mediterranean, as well as on the Atlantic and Pacific coasts of North and South America and in the coastal waters of Japan, though little material on the true effects on the avifauna in that area has become available thus far. It is likely that oil pollutions of such extent will also damage bird species in the oceanic pelagial such as Procellariiformes though we are still insufficiently informed on this issue. Thus far the most destructive damages to bird life have been noticed on the pelagial of the bordering seas and off coastal waters. Even purely littoral species 
(Charadriiformes) have suffered from oil pollution at the rim of the surf as Rittinghaus (1956) first described. As far as the kind of species is concerned, Common Scoters come first (own observations); they are followed by Guillemots, Razorbills, and finally Red-throated Divers. This experience was gained in winter when the species mentioned are migrating, either to their winter quarters or breeding areas. Wildfowl (Anatidae), wintering by the hundreds and thousands, on the Baltic Sea are particularly endangered, especially when the Baltic begins to freeze in its eastern part and thereby forcing the birds to accumulate in the western area. Part of those freshwater species use the sea as their winter quarter.

According to PALUdan (1962), in the Danish waters (chiefly Baltic Sea) there accumulate 600,000 Eiders on an average during the winter; this figure is likely to represent the whole population of Western and Northern Europe, including Iceland, Spitzbergen, Franz-Josephs-Land, and Nowaja Selmja. From bird ringing studies we know that certain populations, dispersed over vast areas during their breeding season, will concentrate in quite restricted localities during winter or certain other times, such as their moulting period. The concentrated moulting of almost all populations of Sheld-duck (Tadorna tadorna) in the Bight of Helgoland, above all on the "Großer Knechtsand", is the best known example of temporary accumulation in North-Western Europe (Goethe 1961b, c). A catastrophe in the extent of that of the "Gerd Maersk" accompanied by northerly winds and in August, consequently could eliminate the existence of the mentioned duck species in Europe at once. The alarming decrease in the world population of the Long-tailed Duck (Clangula byemalis), which winters in large numbers on the Baltic Sea, seems by the way also due chiefly to oil pollution. The example of the "Torrey Canyon" shows that also littoral, at least the temporarily insular breeding bird populations, may experience considerable losses when oil pollution occurs in late winter or in spring.

\section{CONCLUSION}

It should be mentioned here that the extension of routine oil pollutions has generally decreased due to the "International Convention for the Prevention of Pollution of the Sea by Oil" (London 1954, with amendments 1962), as well as to the activities of the "Inter-Governmental Maritime Consultative Organization". The convention bars the whole Baltic and North Sea, as well as large parts of the Mediterranean Sea, and of the Eastern Atlantic from the releasing of oil residues. Nevertheless, the dangers of catastrophes in the form of ship collisions is growing as a function of the steadily increasing oil fleet and the size of single tankers. It will always be impossible to completely exclude collisions. And there is no means available as yet to render oil released into the sea ineffective in regard to causing detrimental effects to birds. The only preventive measures to be taken are more caution in technical and navigational respects.

I wish to add here that the institute headed by myself is maintaining a survey service in cooperation with the German Federal Ministry for Transport (sea admin- 
istration) along the coast, enabling us to examine oil pollution effects on birdlife rather precisely and to trace their causes to a certain extent as well.

A prerequisite for the study of oil pollution effects on sea bird populations is the accurate knowledge of the marine avifauna previous to any accident. The foundation of a "Standing Committee for the Coordination of Sea Bird Research" on the occasion of the "14th International Ornithological Congress" at Oxford in 1966 represents therefore an important step forward in avifauna oil pollution studies.

\section{SUMMARY}

1. Oil pollution of the sea, especially damage of oil tankers, may cause severe effects on populations of sea and coastal birds, especially as far as bird aggregations in winter quarters or breeding places are concerned.

2. Examples of oil pollution effects on birds are given and the most severely affected species of European waters quoted.

\section{LITERATURE CITED}

ECKE, H., 1957. Weltproblem Olpest. In: Fünf Jahre Seevogelschutz. Festschrift Verein Jordsand. Hrsg. von W. Meise. Hamburg, 73-84.

Central Secretariat, 1967. The President's letter. Rep. int. Coun. Bird Preserv. (Br. Sect.) No 11.

GoEtHE, F., 1954. Deutscher Olpestbericht für 1952. NachrBl. Naturschutz Landschaftspflege $25,1-3$.

- 1961a. Deutscher Olpestbericht 1953-1961. Ber, int. Rat Vogelschutz (Dt. Sekt.) 1, 60-61.

- 1961b. A survey of moulting Shelduck on Knechtsand. Br. Birds 54, 106-115.

- 1961c. The moult gatherings and moult migration of Shelduck in North-West Germany. Br. Birds 54, 145-161.

Kunzemann, P., 1953. Die Entenkatastrophe von Hohwacht. Orn. Mitt., Göttingen 5, 111-113.

Paludan, K., 1962. Ederfuglene i de Danske Farvande. Dansk Vildtunders. 10, 5-86.

Rrttinghaus, H., 1956. Erwas über die "indirekte" Verbreitung der Olpest in einem Seevogelschutzgebiet. Orn. Mitt., Göttingen 8, 43-46.

\section{Discussion following the paper by GoETHE}

Prarson: I think it's time to say that the sea-bird species most affected by oil pollution are members of the Alcidae family, in particular the guillemots and puffins. In making observam tions on the feeding of a number of sea-bird species off the North Coast of England, I noted that the surface feeding species, i. e. gulls, terns, and fulmars, tended to feed in patches of roughened water, whereas the auks would dive in smooth water. This is of probable significance in explaining the greater effect of oil pollution on the Alcidae. Have you any observations which would confirm or add to our knowledge on this question?

GoETHE: We have made no comparable observations in the Helgoland Bight, where the composition of sea-bird species differs from that of the British Isles. The Alcidae for instance mostly arrived oiled and therefore caused creatures to move off the German coast. On the other hand we recorded numerous oiled gulls in our waters. 